\title{
Stage-specific and differential expression of gap junctions in the mouse ovary: connexin-specific roles in follicular regulation
}

\author{
C. S. Wright ${ }^{1}$, D. L. Becker ${ }^{2}$, J. S. Lin ${ }^{3}$, A. E. Warner ${ }^{2}$ \\ and K. Hardy ${ }^{1}$ \\ ${ }^{1}$ Department of Reproductive Science and Medicine, Division of Paediatrics, Obstetrics \\ and Gynaecology, Imperial College School of Medicine, Hammersmith Hospital, Du Cane \\ Road, London W12 ONN, UK; ${ }^{2}$ Department of Anatomy and Developmental Biology, \\ University College London, Gower Street, London WC1 6BT, UK; and ${ }^{3}$ Department of \\ Anatomy with Radiology, School of Medicine, University of Auckland, New Zealand
}

Gap junction communication plays an essential role in follicle growth. Immunocytochemistry and confocal microscopy were used to examine the expression of gap junction connexins of the $\alpha$ and $\beta$ subfamilies in follicles from primordial to preovulatory stages in the ovaries of prepubertal and adult mice. Connexin-specific antibodies detected $\alpha_{1}, \alpha_{4}, \alpha_{6}, \beta_{1}, \beta_{2}$ and $\beta_{4}$ connexins within follicles. In adult ovaries connexin immunolabelling was stronger in larger (more mature) follicles than it was in smaller follicles, with comparatively reduced labelling detected in prepubertal ovaries. In healthy follicles, labelling for $\alpha$ subfamily con- nexins was detected between granulosa cells, whereas labelling for $\boldsymbol{\beta}$ subfamily connexins was found in the theca. Labelling for $\beta$ subfamily connexins and $\alpha_{4}$ connexin (preantral stage) was detected on the oocyte surface membrane. In atretic follicles, labelling for $\boldsymbol{\beta}_{4}$ connexin appeared between the granulosa cells. These results demonstrate that $\alpha$ and $\beta$ connexin subfamilies are segregated to separate cellular compartments in the mouse follicle. The results are discussed in the light of possible roles for differential gap junctional communication in the regulation of folliculogenesis, oocyte maturation and atresia.

\section{Introduction}

In the developing ovarian follicle, the oocyte is separated from the local blood supply by an increasing number of granulosa cell layers, the cells of the theca externa being the only follicle cells in direct contact with ovarian capillaries. In this avascular system, intercellular communication between the oocyte and the surrounding somatic cells (the granulosa and theca) is essential for the correct functioning and development of the follicle. An important route for this interaction is provided by gap junctions that occur between follicular cells (Albertini and Anderson, 1974; Anderson and Albertini, 1976).

Gap junctions form channels that directly link the cytoplasm of adjoining cells, and are present in almost all adult tissues (for review, see Kumar and Gilula, 1996). These channels are composed of two opposing hexameric hemi-channels (connexons), consisting of six transmembrane protein subunits known as connexins (Goodenough, 1976). At least seventeen members of the connexin protein family have been sequenced and allocated to subfamilies $-\alpha, \beta, \gamma$ and $\delta-$ on the basis of sequence homology (Sohl et al., 1998; for review, see Kumar, 1999).

Gap junction communication allows the direct exchange between cells of ions and small molecules such as

Email: catherine.wright@ic.ac.uk
CAMP and inositol 1,4,5-trisphosphate $\left(\mathrm{IP}_{3}\right)$ (for review, see Kumar and Gilula, 1996). In the ovarian follicle, gap junctions facilitate the uptake by the oocyte of nutrients such as amino acids from somatic cells (Biggers et al., 1967). Gap junctions mediate metabolic co-operation between the oocyte and its somatic companion cells (Heller et al., 1981) and transmit endocrine, paracrine and growth factor effects (for review, see Eppig, 1991). Gap junction communication may also play a role in the co-ordination of follicular growth and steroid hormone production (Grazul Bilska et al., 1997). Follicular gap junctions maintain the meiotic arrest of the oocyte in the follicle via low tonic amounts of cAMP signalling from the granulosa to the oocyte (Dekel, 1988; Downs et al., 1989; Eppig, 1989). Follicular gap junction communication also plays a role in the final maturation of the oocyte by LH-induced signalling pathways (Dekel, 1988).

Northern blotting, in situ hybridization and RT-PCR have detected mRNA for eight connexin types $\left(\alpha_{1}(\mathrm{C} \times 43)\right.$, $\alpha_{4}$ (Cx37), $\alpha_{5}$ (Cx40), $\alpha_{6}$ (Cx45), $\alpha_{9}$ (Cx60), $\beta_{1}$ (Cx32), $\beta_{2}$ (Cx26), $\left.\beta_{5}(\mathrm{Cx} 30.3)\right)$ in the ovaries of a number of species (Beyer et al., 1992; Reed et al., 1993; for review, see Grazul Bilska et al., 1997; Itahana et al., 1998). Immunocytochemistry has confirmed the presence of five of these connexins: $\alpha_{1}, \alpha_{4}, \alpha_{6}, \beta_{1}$ and $\beta_{2}$ (for review. see Grazul Bilska et al., 1997, 1998; Lenhart et al., 1998; Johnson et al., 1999). In addition, studies have shown that cultured 
ovaries of mouse $\alpha_{1}$-knockouts have very poor follicular development (Juneja et al., 1999), and $\alpha_{1}$-heterozygotes have reduced fertility (C. Lo, personal communication). $\alpha_{4}$-Knockout mice are also infertile (Simon et al., 1997).

Investigations of oocyte and follicle maturation in vitro have been undertaken mainly in mice. However, to date, there has been no systematic description of connexin expression in this species. In the present study, the spatio-temporal distribution of connexins forming gap junctions in the mouse ovarian follicle during follicular maturation were studied with the aim of increasing understanding of the role of gap junctions in the follicle.

\section{Materials and Methods}

\section{Animals and tissue preparation}

$\mathrm{F}_{1}(\mathrm{C} 57 \mathrm{BL} / 6 \times \mathrm{CBA} / \mathrm{Ca}$; Olac, Bicester) female mice of either 3-6 weeks old (adult) or 12 days old (prepubertal) were used. At least five mice were included in each animal group. Animals were killed by cervical dislocation, and their ovaries were immediately dissected free and collected into filtered PBS ('A' Oxoid, Basingstoke). Ovaries were further cleaned of all fat and other tissue, fixed in $4 \%$ paraformaldehyde overnight (Sigma, Poole), and then transferred to $30 \%(\mathrm{w} / \mathrm{v})$ sucrose $(\mathrm{BDH}$, Poole) in PBS solution overnight. The tissue was then coated in OCT compound $(\mathrm{BDH})$, and frozen by immersion in an isopentane $(\mathrm{BDH})$ slush bath surrounded by liquid nitrogen. Sections $(10-20 \mu \mathrm{m})$ were cut on a Bright cryostat, and mounted onto poly-lysine-coated slides (Polysine, BDH). Hearts and livers of 6 -week-old mice were dissected at the time of ovary collection and processed as above for use as controls.

\section{Generation and characterization of monoclonal and polyclonal antibodies}

Peptides matching sequences from the intracellular loop of connexins $\alpha_{1}(\mathrm{C} \times 43)$ and $\beta_{1}(\mathrm{C} \times 32)$ were synthesized by Immune Systems, Bristol. The following peptides were used: $\alpha_{1}$ : EIKKFKYGIEEH; $\beta_{1}$ : LEGHGDPLHLEE. Peptides were coupled at the C-terminal end to bovine thyroglobulin at a final molar ratio peptide:thyroglobulin of 40-60:1. Coupled peptides were used to generate monoclonal antibodies in mice by the Monoclonal Antibody Unit, University College London. Two injections of peptide were made, 4 weeks apart. One week after the second injection, primary screening was carried out on small samples of serum from each mouse by ELISA with the immunizing peptide and checked by immunolabelling on sections to identify samples that recognized the parent connexin. Mice that were generating promising antibodies were killed 3 weeks later, the spleens were removed and homogenized, and red cells and excess protein were removed. Spleen cells were fused to JK immortal myeloma cells with $50 \%(\mathrm{v} / \mathrm{v})$ polyethylene glycol (Sigma) to generate antibody secreting hybridoma cells. After fusion, cells were plated onto a feeder containing $10 \%(\mathrm{w} / \mathrm{v})$ hybridomaenhancing substance and surviving hybridomas were cloned. An ELISA screen identified clones secreting antibodies that recognized the immunizing peptide, followed by immunocytochemistry on sections to confirm connexin recognition. Clones generating satisfactory antibodies by both criteria were then expanded and supernatants were taken for further characterization.

Selected antibodies were screened on frozen sections of paraformaldehyde-fixed heart tissue, which expresses predominantly $\alpha_{1}$ connexin $(\mathrm{C} \times 43)$, and liver, which expresses both connexins $\beta_{1}(\mathrm{Cx} 32)$ and $\beta_{2}(\mathrm{Cx} 26)$. These screens revealed several monoclonal antibodies for the two connexins and monoclonal antibodies $1 \mathrm{~A}\left(\alpha_{1}\right)$ and $2 \mathrm{~A}$ $\left(\beta_{1}\right)$ were chosen for further analysis. Both antibodies gave excellent, specific labelling of their parent proteins. Immunolabelling was abolished when the peptide used as an antigen was included in the labelling mixture. The connexin specificity of the antibodies was confirmed by assay on pre-implantation mouse embryos, which express predominantly $\alpha_{1}$ connexin (Becker et al., 1995) and sections of chick and mouse limb buds, which express both $\alpha_{1}$ and $\beta_{1}$ connexins (Makarenkova et al., 1997). The monoclonal antibodies reproduced precisely the labelling patterns published using polyclonal peptide antibodies to the same region of the connexin proteins (Gap 15, Des 1 and Des 5; Becker et al., 1995; Makarenkova et al., 1997). This finding indicates that these monoclonal antibodies have wide species specificity. Given the sequence conservation between the same connexin cloned from a variety of species, this conservation is not unexpected, and indicates that these monoclonal antibodies will be widely useful.

Epitope mapping of monoclonal antibodies $1 \mathrm{~A}$ and $2 \mathrm{~A}$ was carried out by 'peptide walking', in which peptides overlapping small regions along the length of the immunizing peptide were tested for the ability to compete with the antibodies for their binding sites and abolish immunolabelling. These experiments showed that the epitope for monoclonal antibody $1 \mathrm{~A}$ lay within amino acids 136-142 of $\alpha_{1}$ connexin (KYGIEEH) and that for $2 \mathrm{~A}$ lay within amino acids $112-119$ of $\beta_{1}$ connexin (GDPLHLEE). These epitopes are close to, but not identical with, the epitopes identified for the peptide polyclonal antibodies Gap 13, Gap 15 and Des 5 (Becker et al., 1995).

$\beta_{4}$ connexin (Cx31.1) antibodies were raised to a 15 amino acid sequence matching hydrophilic residues at the C-terminal end of the $\beta_{4}$ sequence (rat and mouse). The sequence selected is specific to $\beta_{4}$ connexin and has no homology with other known connexin sequences. The peptide was synthesized, conjugated to keyhole limpet haemocyanin (KLH, Sigma) and polyclonal antibodies raised in rabbits by Research Genetics Inc., AL.

\section{Immunocytochemistry and confocal microscopy}

Immunolabelling for connexins $\alpha_{1}(\mathrm{Cx} 43), \alpha_{4}(\mathrm{Cx} 37), \alpha_{5}$ (Cx40), $\alpha_{6}(\mathrm{Cx} 45), \beta_{1}(\mathrm{Cx} 32), \beta_{2}(\mathrm{C} \times 26), \beta_{4}(\mathrm{C} \times 31.1)$ and $\beta_{6}$ 
Table 1. Amino acid sequences of peptides used as immunogens to produce primary antibodies used to detect connexins ${ }^{a}$

\begin{tabular}{|c|c|c|c|c|c|}
\hline Antibody & Type $^{b}$ & Connexin & Amino acid sequence & Location & Reference \\
\hline R45 & $\mathrm{RP}$ & $\alpha_{6}(45)$ & QYTELSNAKIAYKQN & Carboxyl tail & Coppen et al., 1998 \\
\hline Gap 15 & $\mathrm{RP}$ & $\alpha_{1}(43)$ & EIKKFKYGIEEH $\underline{C}$ & Cytoplasmic loop 131-142 & Becker et al., 1995 \\
\hline $1 \mathrm{~A}$ & MM & $\alpha_{1}(43)$ & EIKKFKYGIEEH & Cytoplasmic loop 131-142 & \\
\hline Anti- $\alpha_{5}$ & $\mathrm{RP}$ & $\alpha_{5}(40)$ & AELSCNKEVNG & Cytoplasmic loop 225-270 & Coppen et al., 1998 \\
\hline Gap 23 & $\mathrm{RP}$ & $\alpha_{4}(37)$ & ALLAIEHQMAKIC & Cytoplasmic loop 126-137 & Carter et al., 1996 \\
\hline Anti- $\alpha_{4}(\mathrm{DP})$ & RP & $\alpha_{4}(37)$ & VHL to QYV & C-terminus 229-333 & Goliger and Paul, 1994 \\
\hline Des 5 & $\mathrm{RP}$ & $\beta_{1}(32)$ & LEGHGDPLHLEEC & Cytoplasmic loop 108-119 & Monaghan et al., 1994 \\
\hline Des 1 & $\mathrm{RP}$ & $\beta_{1}(32)$ & EKKMLRLEGH-GHLEEVKRHK & $\begin{array}{l}\text { Cytoplasmic loop 102-112 } \\
+116-124\end{array}$ & Rahman and Evans, 1991 \\
\hline $2 \mathrm{~A}$ & MM & $\beta_{1}(32)$ & LEGHGDPLHLEE & Cytoplasmic loop 108-119 & \\
\hline Anti- $\beta_{4}$ & $\mathrm{RP}$ & $\beta_{4}(31.1)$ & Proprietary & Proprietary & \\
\hline Anti- $\beta_{6}$ & $\mathrm{RP}$ & $\beta_{6}(30)$ & Proprietary & Proprietary & \\
\hline Des 3 & $\mathrm{RP}$ & $\beta_{2}(26)$ & FMKGEIKNEFKDIEC & Cytoplasmic loop 106-119 & Monaghan et al., 1994 \\
\hline $28 \mathrm{H}$ & MM & $\beta_{2}(26)$ & SEFKDIEEIKTQ & Cytoplasmic loop 113-124 & Diez et al., 1999 \\
\hline Gap 10 & $\mathrm{RP}$ & $\beta$ sub-family & MNWTGLYTLLSGVNRHSTAIG & Amino terminus of $\beta_{1} 1-21$ & Rahman and Evans, 1991 \\
\hline
\end{tabular}

${ }^{a}$ Amino acid sequences for $\beta_{4}(C \times 31.1)$ and $\beta_{6}(C \times 30$, Zymed $)$ antibodies are not available.

bType of antibody: RP, rabbit polyclonal; MM, mouse monoclonal.

(Cx30) was performed with primary antibodies that had been raised against short peptide sequences of connexins as described by Becker et al. (1995). Antibodies to $\alpha_{4}, \beta_{4}$ and $\alpha_{6}$ connexins were kind gifts of David L. Paul (Harvard Medical School), Colin Green (University of Auckland) and Rob Gourdie (Medical University of South Carolina), respectively. Details of all primary antibodies are given (Table 1). Secondary flourescein isothiocyanate (FITC)-conjugated antibodies (Dako, Copenhagen) were either swine anti-rabbit or rabbit anti-mouse, according to the primary antibody used. Most antibodies were diluted in filtered PBS to concentrations of 1:40-50 except Gap 23 and anti- $\beta_{4}$ connexin, which were used at 1:100 and $1: 1000$, respectively.

In brief, slides were washed with filtered PBS (all PBS was filtered with a $0.22 \mu \mathrm{m}$ Millipore filter), incubated with a 0.1 mol lysine $\mathrm{I}^{-1}$ (Sigma) in PBS block containing $0.1 \%(\mathrm{v} / \mathrm{v})$ Triton-X100 (Sigma) for $30 \mathrm{~min}$ at room temperature, incubated with the primary antibody directed against the connexin of interest for $1 \mathrm{~h}$ at $37^{\circ} \mathrm{C}$, washed three times with PBS and incubated with a secondary antibody for $1 \mathrm{~h}$ at $37^{\circ} \mathrm{C}$ in the dark, washed twice with PBS, then washed with $1 \mu \mathrm{g} \mathrm{ml}-1$ propidium iodide (Sigma) in PBS for $2 \mathrm{~min}$, and finally washed twice with PBS. An avidin-biotin (BDS, Cambridge) multiplication step was also used in conjunction with anti- $\alpha_{4}(D P)$. Slides were mounted with Citiflour (Chem.lab, Canterbury) and immediately observed on a Leica TCS4D confocal microscope. Confocal images were collected and stored digitally for subsequent analysis of gap junction distribution.

The specificity of connexin labelling was checked by: (1) using multiple antibodies for connexins $\alpha_{1}$ (Cx43), $\beta_{1}$ (Cx32) and $\beta_{2}$ (Cx26); (2) parallel staining for connexins in mouse heart, liver and skin sections (positive controls, Fig. 1); (3) omitting the primary antibody for each connexin (negative control); and (4) peptide competition experi- ments (when peptides were available) for $\alpha_{1}$ (using Gap 15 antibody), $\beta_{1}$ (Des 5 antibody) and $\beta_{2}$ (Des 3 antibody) connexins, performed as described by Becker et al. (1995). Examples are shown of immunolabelling to check the ability of antibodies $1 \mathrm{~A}$ (Fig. 1a), 2A (Fig. 1b) and anti- $\beta_{4}$ (Fig. 1c) to recognize their parent proteins in frozen sections. Antibody 1A (Fig. 1a) identified rat heart intercalated discs of the cardiac myocytes, the locations of $\alpha_{1}$ connexin (Cx43)-containing gap junctions (Becker et al., 1995). Antibody 2A (Fig. 1b) detected $\beta_{1}$ connexin (Cx32)containing gap junctions in mouse liver cell plasma membranes (Becker et al., 1995); and anti- $\beta_{4}$ recognized gap junctions in rat epidermis (Fig. 1c). There was no immunolabelling of connexins in negative controls. Peptide competition experiments for $\alpha_{1}, \beta_{1}$ and $\beta_{2}$ connexins showed that peptide concentrations of 1:100 reduced labelling markedly, and concentrations of 1:10 and undiluted peptide $\left(10 \mu \mathrm{g} \mathrm{ml}^{-1}\right)$ prevented antibody labelling.

\section{Western blotting}

Protein was extracted from rat heart and intercalated discs (Colaco and Evans, 1981), mouse liver plasma membranes (Ali et al., 1990) and rat epidermis. Blots were resolved by SDS-PAGE using $10 \%$ or $12.5 \%$ acrylamide gels. All other antibodies had been characterized previously (Table 1). Western blotting was carried out as described by Burnette (1981) and the location of antigens was determined with an enhanced chemiluminescence kit (ECL+plus; Amersham Pharmacia Biotech, Little Chalfont). It has been reported frequently that good immunocytochemical staining is not necessarily associated with good recognition of the denatured proteins on western blots. In accordance with these observations, the monoclonal antibodies tested here showed the same variability. However, both monoclonal antibodies $1 \mathrm{~A}$ and $2 \mathrm{~A}$ and 

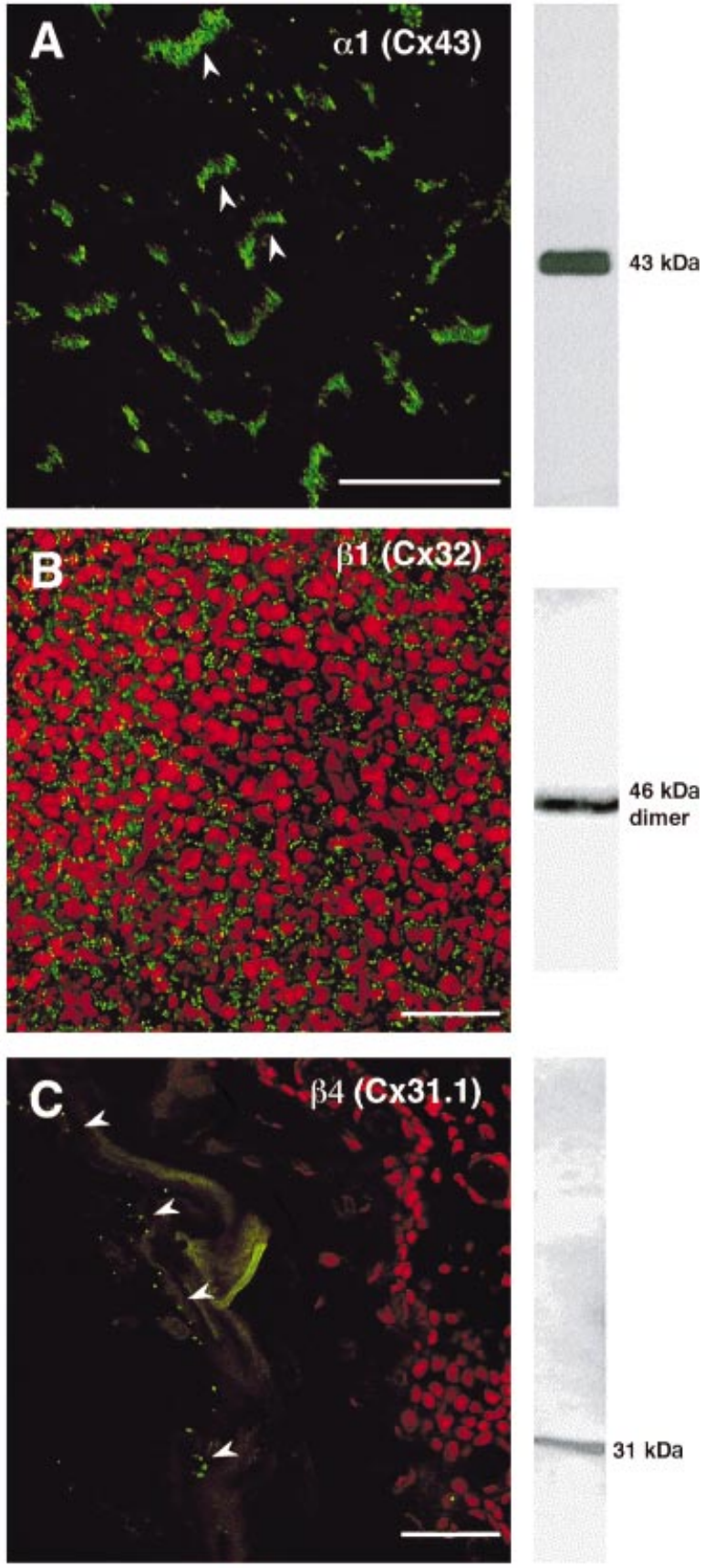

Fig. 1. Connexin antibodies $1 \mathrm{~A}, 2 \mathrm{~A}$ and anti- $\beta_{4}$ recognize their parent proteins. (A) Monoclonal antibody $1 \mathrm{~A}$ identifies the intercalated discs (arrowheads) and punctate gap junctions composed of $\alpha_{1}$ connexin $(\mathrm{C} \times 43)$ that lie in the parallel membranes of myocytes in a frozen section of rat heart. The panel to the right shows the single clear band at $43 \mathrm{kDa}$ identified on a western blot against protein isolated from rat heart. The band is relatively broad and may include the minor bands that indicate the phosphorylated forms of the connexin protein. (B) Frozen section through mouse liver revealing extensive punctate labelling of $\beta_{1}$ (Cx32)-containing gap junctions in the intercellular membranes of liver cells identified by monoclonal antibody 2A. The panel to the right shows a western blot against protein isolated from mouse liver cell membranes with $2 \mathrm{~A}$. The band recognized by $2 \mathrm{~A}$ runs at anti- $\beta_{4}$ polyclonal identified single bands at positions appropriate for connexins $\alpha_{1}$ (Cx43), $\beta_{1}(\mathrm{Cx} 32)$ and $\beta_{4}$ (Cx31.1), respectively (Fig. 1 ). The size of the protein identified by each antibody was determined for each gel by plotting the distance travelled by protein markers against their molecular weight, measuring the position of the band identified by the antibody under test, and reading the molecular weight of the stained protein from the graph. The estimated size for the band recognized by each antibody is indicated (Fig. 1). The blots for testing $2 \mathrm{~A}$ were run on non-reducing $10 \%$ acrylamide gels. The $\beta_{1}$ connexin protein is notorious both for its sensitivity to the percentage of acrylamide in the gel and a tendency to form dimers and trimers (Green et al., 1988). In addition, Green et al. (1988) demonstrated that when protein loading of a gel is relatively low, the dimeric form of the $\beta_{1}$ protein dominates. Because of this anomalous behaviour, in the illustrated $10 \%$ gel, the $\beta_{1}$ dimer was prominent at the predicted size of $46 \mathrm{kDa}$ (Fig. 1). Parallel samples of protein extracted from mouse heart and liver showed that $1 \mathrm{~A}$ recognized proteins only in the heart while $2 \mathrm{~A}$ recognized proteins only in the liver, according to the expression patterns of the parent proteins.

\section{Results}

Propidium iodide labelling of cell nuclei allowed clear identification of follicles at all developmental stages. The ovaries of 12-day-old prepubertal mice contained primordial, primary and secondary follicles. Ovaries of adult mice contained a range of follicle stages from primordial to antral and preovulatory follicles (see Fig. 2 for follicle staging). Healthy follicles of the same developmental stage in 3-6-week-old (adult) mice showed similar immunolabelling, and observations on adult animals are treated as a single group. Differences in nuclear shape and spatial organization differentiated between stromal, thecal, granulosa and oocyte cells. Connexins in gap junctions were visible as discrete spots or lines between cells. Immunolabelling results are summarized (Tables 2 and 3 ).

\section{Labelling of connexins in ovarian follicles of prepubertal mice}

Gap junctions containing $\alpha_{1}$ connexin (Cx43) were detected by Gap 15 between granulosa cells of secondary follicles in the central region of ovaries from 12-day-old mice. Expression was similar to that in secondary follicles of adult animals (Table 2). Primordial and primary follicles in the outer regions of the ovaries did not show any

$46 \mathrm{kDa}$, the predicted position for $\beta_{1}$ protein run at low loading on a $10 \%$ acrylamide gel (Green et al., 1988). (C) Frozen section through rat skin labelled with anti- $\beta_{4}$. Punctate gap junctions are visible in the epidermis (arrowheads). The panel to the right shows a western blot of the single band at $31 \mathrm{kDa}$ recognized by this antibody. Scale bars represent $50 \mu \mathrm{m}$. 


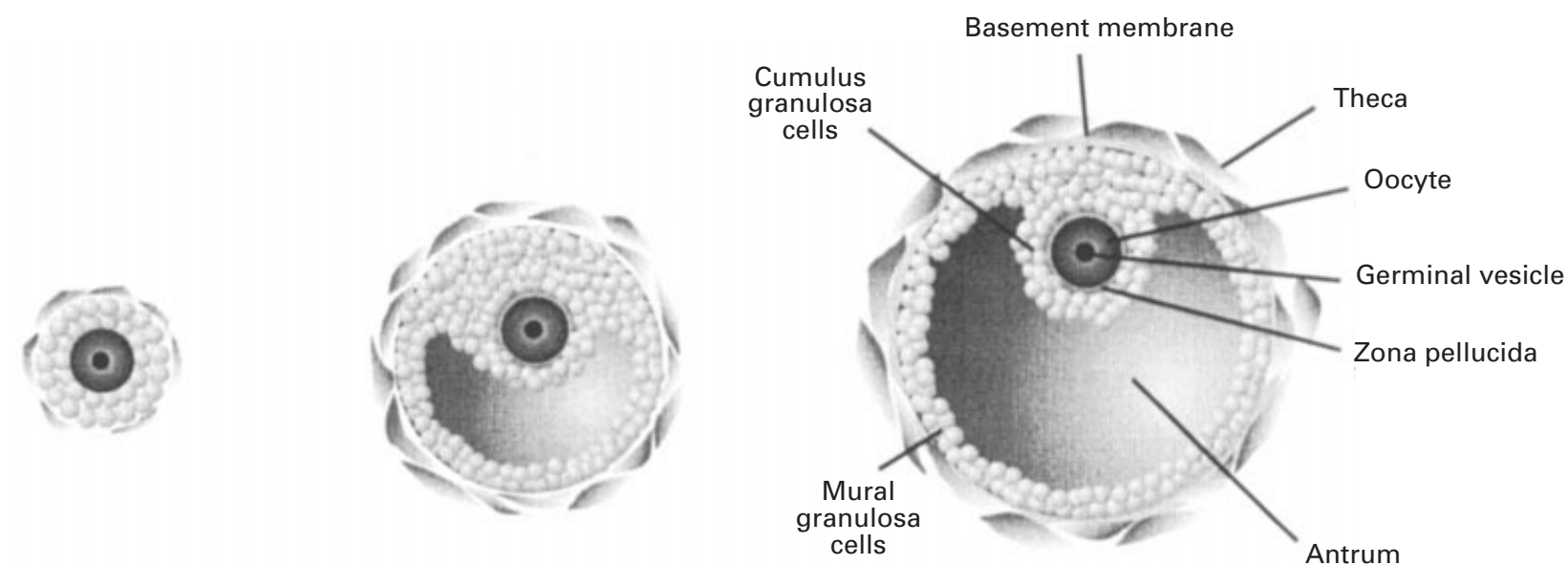

Preantral follicle

Antral follicle

Preovulatory follicle

Fig. 2. Classification of the stages of mouse ovarian follicular development examined in the present study. Stages are grouped into preantral (primary to large preantral: approximately 50-200 $\mu \mathrm{m}$ ), antral (early antral to large antral: approximately $250-500 \mu \mathrm{m}$ ) and preovulatory (approximately $600 \mu \mathrm{m}$ ) stages.

detectable connexin expression (Fig. 3a,b). Gap junction density was greater between mural granulosa cells than between cumulus cells. The $\beta_{1}$ connexin (Cx32) antibodies Des 1, Des 5 and 2A showed weak labelling of gap junctions between theca cells in some central secondary follicles, and also some weak labelling of the oocyte (Table 2). Although $\beta_{2}$ connexin (Cx26) antibodies labelled the ovarian epithelium, no follicular labelling was seen for other antibodies (Table 2).

\section{Labelling of connexins in ovarian follicles of adult mice}

In general, the labelling intensity of healthy follicles increased with follicle size (Figs $3 c$ and $4 b$; Table 3). Primordial and primary follicles had some low-intensity labelling, whereas large antral and Graafian follicles had high-intensity labelling.

$\alpha_{1}$ connexin (Cx43) was detected only between follicle granulosa cells (Fig. 3c). Preantral follicles (primordial to late preantral stages) showed less labelling than was seen in larger antral follicles (early antral to preovulatory stages; Table 3). The extent of labelling of secondary follicles for $\alpha_{1}$ connexin was similar to that seen in prepubertal animals. An oblique section of a large antral follicle revealed dense immunolabelling of $\alpha_{1}$ connexin proteins, which were widely distributed between granulosa cells (Fig. 3d). There was dense expression of $\alpha_{1}$ connexin-containing gap junctions between mural cells close to the basal lamina (which appeared linear) and between cells close to the antrum (which appeared more macular), and a lower density in between (Figs $3 \mathrm{~d}$ and $4 \mathrm{e}$ ). Both $\alpha_{1}$ antibodies 1A (monoclonal, Fig. 3c) and Gap 15 (polyclonal, Fig. 3d) - gave similar labelling patterns (Table 3).

Immunolabelling with anti- $\alpha_{4}(\mathrm{DP})$ for $\alpha_{4}$ connexin (Cx37) on the oocyte surface of a preantral follicle is
Table 2. Immunolabelling by antibodies directed against connexins of gap junctions in ovarian follicles of 12-day-old prepubertal mice

Immunolabelling of connexins in gap junctions of prepubertal follicles

\begin{tabular}{llccc}
\hline Connexin & Antibody & Theca & Granulosa & Oocyte \\
\hline$\alpha_{6}(45)$ & R45 & - & - & - \\
$\alpha_{1}(43)$ & Gap 15 & - & ++ & - \\
$\alpha_{1}(43)$ & 1A & - & ++ & - \\
$\alpha_{4}(37)$ & Gap 23 & - & - & - \\
$\beta_{1}(32)$ & Des 1 & + & - & $+/$ \\
$\beta_{1}(32)$ & Des 5 & + & - & $+/-$ \\
$\beta_{1}(32)$ & 2A & $+/-$ & - & +- \\
$\beta_{2}(26)$ & Des 3 & - & - & - \\
\hline
\end{tabular}

Immunolabelling was scored as follows: -, no immunolabelling apparent ('none'); +/-, possible immunolabelling ('very weak'); +, a low density of immunolabelling clearly above background ('weak'); ++ , a high density of immunolabelling with plaques visible ('moderate'); +++ , very high density immunolabelling with lines of plaques clearly visible ('strong').

shown (Fig. 3e). Expression of $\alpha_{4}$ on the oocyte was restricted to preantral stages. $\alpha_{4}$ connexins were detected with anti- $\alpha_{4}(\mathrm{DP})$ between granulosa cells in antral follicles (Fig. 3e, inset). In secondary, preantral and early antral follicles, there was weak $\alpha_{4}$ connexin immunolabelling between granulosa cells, which was generally not evenly distributed but was restricted to patches of the granulosa (Table 3). However, Gap 23 detected $\alpha_{4}$ connexincontaining gap junctions widely distributed between granulosa cells in large antral follicles (Fig. 3f), with a gradient of gap junction density from close to the antrum (stronger) to the mural granulosa cells (weaker) (Table 3). 

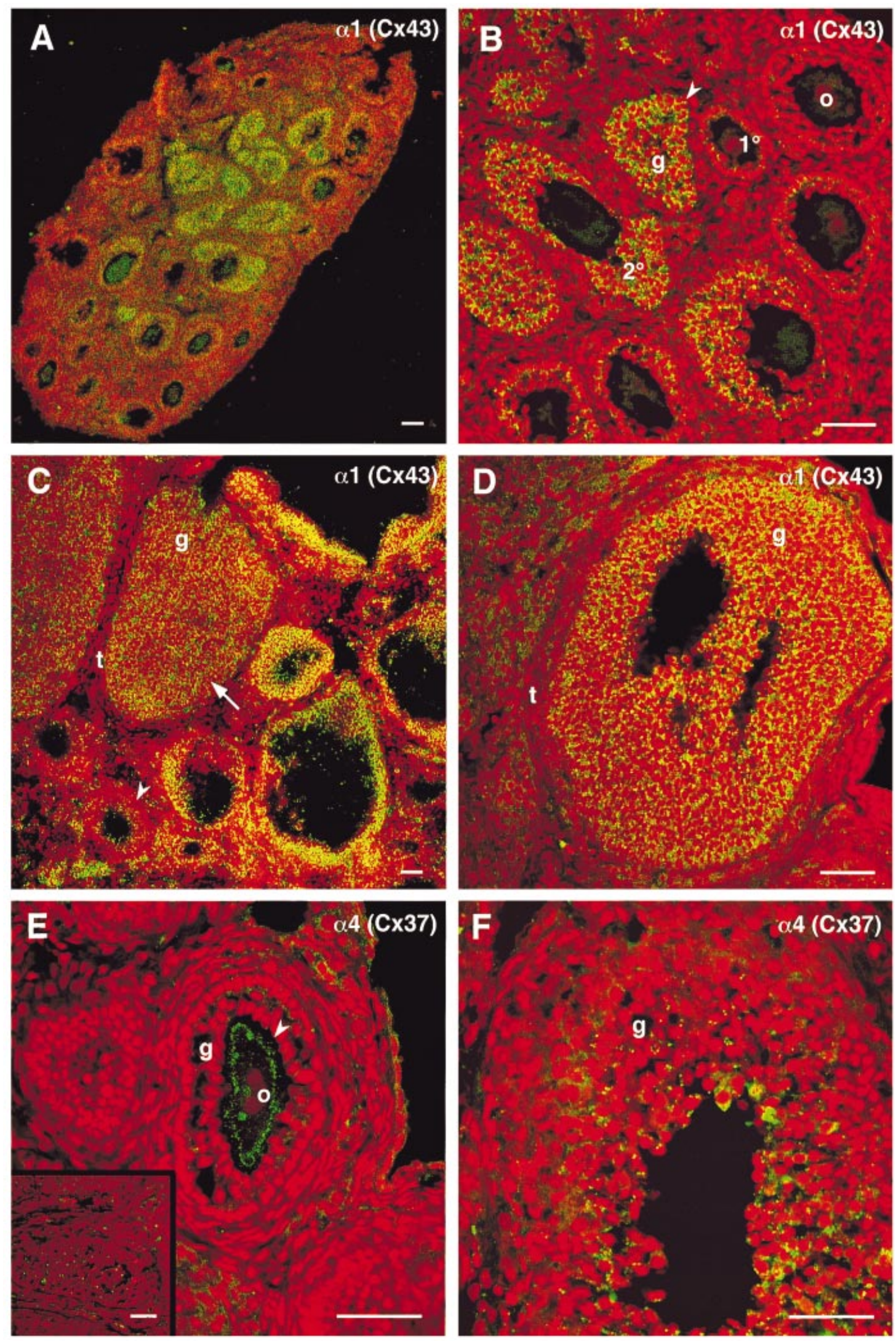
Table 3. Immunolabelling by antibodies directed against connexins of gap junctions in healthy and atretic ovarian follicles of adult mice

\begin{tabular}{|c|c|c|c|c|c|c|c|c|c|c|c|c|c|}
\hline \multirow[b]{3}{*}{ Connexin } & \multirow[b]{3}{*}{ Antibody } & \multicolumn{12}{|c|}{ Immunolabelling of connexins in gap junctions of adult mouse follicles } \\
\hline & & \multicolumn{3}{|c|}{ Preantral } & \multicolumn{3}{|c|}{ Antral } & \multicolumn{3}{|c|}{ Preovulatory } & \multicolumn{3}{|c|}{ Atretic } \\
\hline & & $\mathrm{T}$ & G & $\mathrm{O}$ & $\mathrm{T}$ & G & $\mathrm{O}$ & $\mathrm{T}$ & G & $\mathrm{O}$ & $\mathrm{T}$ & G & $\mathrm{O}$ \\
\hline$\alpha_{6}(45)$ & R45 & - & - & - & - & - & - & - & + & - & - & - & - \\
\hline$\alpha_{1}(43)$ & Gap 15 & - & + & - & - & ++ & - & - & +++ & - & - & + & - \\
\hline$\alpha_{1}(43)$ & $1 \mathrm{~A}$ & - & ++ & - & - & +++ & - & - & +++ & - & - & + & - \\
\hline$\alpha_{5}(40)$ & Anti- $\alpha_{5}$ & - & - & - & - & - & - & - & - & - & - & - & - \\
\hline$\alpha_{4}(37)$ & Gap 23 & - & - & - & - & + & - & - & ++ & - & - & + & - \\
\hline$\alpha_{4}(37)$ & Anti- $\alpha_{4}(\mathrm{DP})$ & - & - & + & - & + & - & - & - & - & - & + & - \\
\hline$\beta_{1}(32)$ & Des 5 & + & - & + & + & - & + & ++ & - & ++ & + & - & - \\
\hline$\beta_{1}(32)$ & Des 1 & + & - & + & ++ & - & + & ++ & - & ++ & + & - & - \\
\hline$\beta_{1}(32)$ & $2 \mathrm{~A}$ & + & - & + & + & - & + & + & - & + & - & - & - \\
\hline$\beta_{4}(31.1)$ & Anti- $\beta_{4}$ & - & - & - & - & - & - & - & - & - & - & ++ & - \\
\hline$\beta_{6}(30)$ & Anti- $\beta_{6}$ & - & - & - & - & - & - & - & - & - & - & - & - \\
\hline$\beta_{2}(26)$ & Des 3 & + & - & + & ++ & - & + & ++ & - & + & - & - & - \\
\hline$\beta_{2}(26)$ & Gap $28 \mathrm{H}$ & + & - & + & ++ & - & + & ++ & - & + & - & - & - \\
\hline$\beta$ subfamily & Gap 10 & + & - & + & ++ & - & + & ++ & - & + & + & - & - \\
\hline
\end{tabular}

Follicle compartments are classified into theca $(\mathrm{T})$, granulosa $(\mathrm{G})$ and oocyte $(\mathrm{O})$.

Immunolabelling was scored as follows: -, no immunolabelling apparent ('none'); $+/-$, possible immunolabelling ('very weak'); +, a low density of immunolabelling clearly above background ('weak'); ++, a high density of immunolabelling with plaques visible ('moderate'); +++, very high density immunolabelling with lines of plaques clearly visible ('strong').

$\alpha_{6}$ connexins ( $\mathrm{Cx} 45$, detected with R45) were restricted to gap junctions between granulosa cells of large antral follicles. $\alpha_{6}$ connexin-containing gap junctions were less frequent, and possessed smaller plaques than did $\alpha_{1}$ containing gap junctions (Fig. 4a).

The distribution of gap junctions containing members of the $\beta$ connexin subfamily in the thecal layer and on the oocyte surface (Fig. 4b) was detected with Gap 10 antibody, which was raised against the amino terminus sequence of $\beta_{1}(\mathrm{C} \times 32)$ and, therefore, recognizes several members of the $\beta$ subfamily. Both preantral and antral follicles have immunolabelling between thecal cells, with stronger labelling in the larger follicles (Fig. 4b). Gap 10 detected $\beta$ subfamily connexins on the oocyte surface, which appeared to be both inside and outside the zona pellucida (Fig. $4 \mathrm{~b}$, inset). Specific labelling for $\beta_{1}$ connexins with Des 1 is shown (Fig. 4c) and confirms the presence of $\beta_{1}$-containing gap junctions between thecal cells and on the oocyte surface. Specific labelling of $\beta_{2}$ con- nexin (Cx26) with Gap 28H, which matches the distribution of $\beta_{1}$ connexin, was demonstrated between thecal cells (Fig. $4 d$ ) and on the oocyte (Table 3 ). It is concluded that gap junctions expressed between thecal cells and on the oocyte surface membrane contain both $\beta_{1}$ and $\beta_{2}$ connexins.

The connexin expression pattern was modified in atretic follicles, which were identified by the presence of pyknotic nuclei in the granulosa cells and degenerated oocytes. Granulosa cells in an atretic follicle expressed fewer $\alpha_{1}$ connexin (Cx43)-containing gap junctions than did granulosa cells in an adjacent healthy follicle (Fig. 4e), indicating that $\alpha_{1}$ connexin expression is suppressed. In healthy follicles, members of the $\beta$ connexin subfamily are not detected between granulosa cells. However, in atretic follicles, granulosa cells express gap junctions containing $\beta_{4}$ connexin (Cx31.1) (Fig. 4f).

Ovarian blood vessel endothelial cells expressed connexins $\alpha_{1}(\mathrm{C} \times 43), \alpha_{4}(\mathrm{Cx} 37), \alpha_{5}(\mathrm{C} \times 40)$ and $\alpha_{6}(\mathrm{C} \times 45)$

Fig. 3. Distribution of connexin types within gap junctions of adult and prepubertal mouse ovarian follicles. Nuclei are stained with propidium iodide (red) and connexins are stained with fluorescein isothiocyanate (FITC) (green). (A) Immunolabelling of $\alpha_{1}$ connexin (Cx43)-containing gap junctions with Gap 15 between granulosa cells of secondary follicles in the central region of a prepubertal ovary. (B) Immunolabelling (arrowhead) of $\alpha_{1}$ connexin with Gap 15 showing expression restricted to the granulosa (g) of inner secondary follicles $\left(2^{\circ}\right)$ but not outer primary follicles $\left(1^{\circ}\right)$ in a prepubertal ovary. (C) Immunolabelling of $\alpha_{1}$ connexin in an adult ovary with $1 \mathrm{~A}$ in gap junctions between granulosa cells ( $g$ ) at several different follicular stages, showing strong expression in large follicles (arrow) and weaker expression in smaller follicles (arrowhead) t: theca. (D) Immunolabelling of $\alpha_{1}$ connexin with Gap 15 in a large antral follicle from an adult ovary showing gap junctions between granulosa cells (g) but not thecal cells (t). (E) Immunolabelling of $\alpha_{4}$ connexin (Cx37) with anti- $\alpha_{4}$ (DP) on the oocyte (o) surface (arrowhead) but not between granulosa cells (g) in an adult preantral follicle, and (inset) between granulosa cells in a larger follicle. (F) Immunolabelling of $\alpha_{4}$ connexin with Gap 23 between granulosa cells (g) in a large antral follicle of an adult ovary. Scale bars represent $50 \mu \mathrm{m}$. 

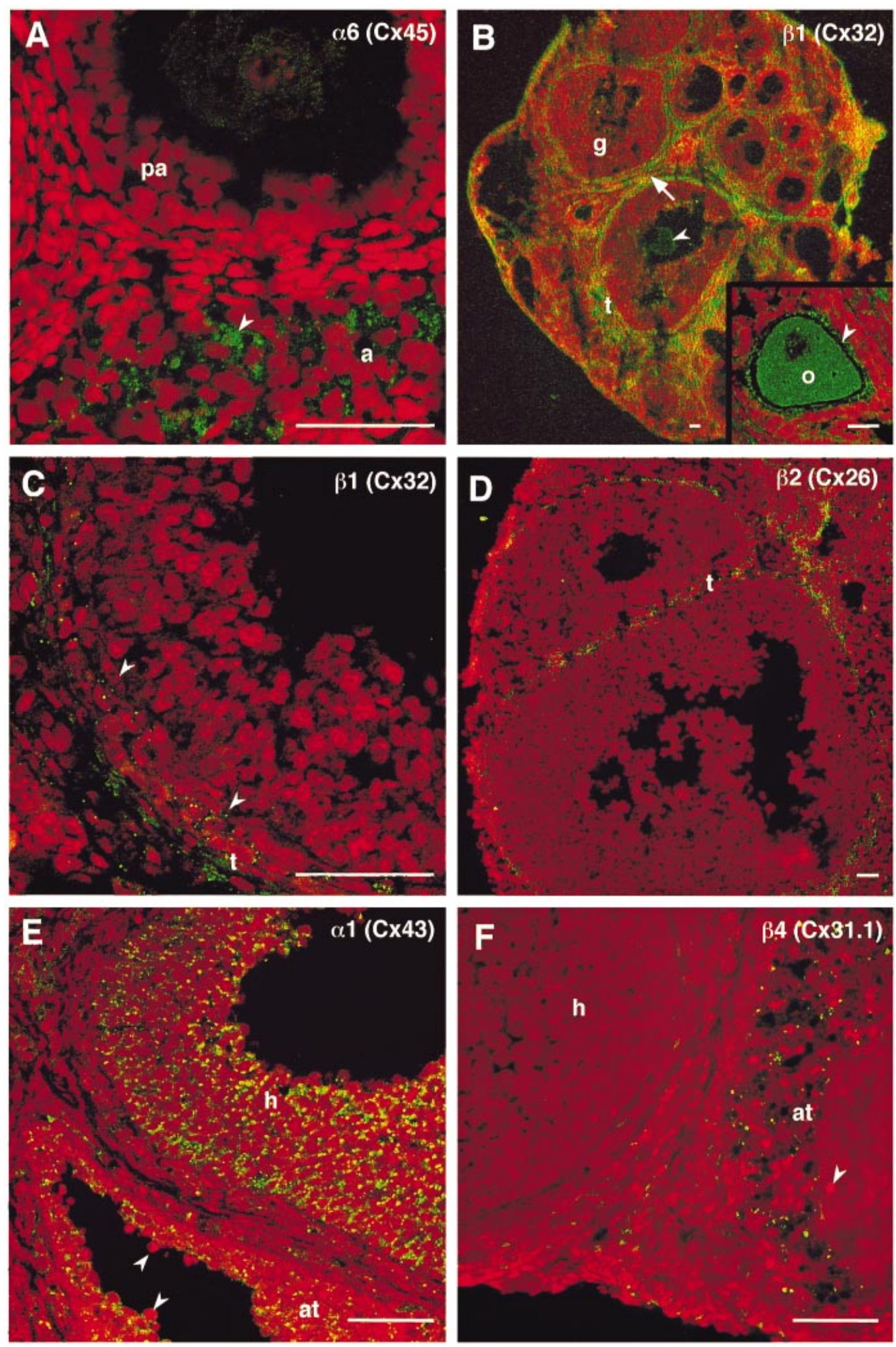

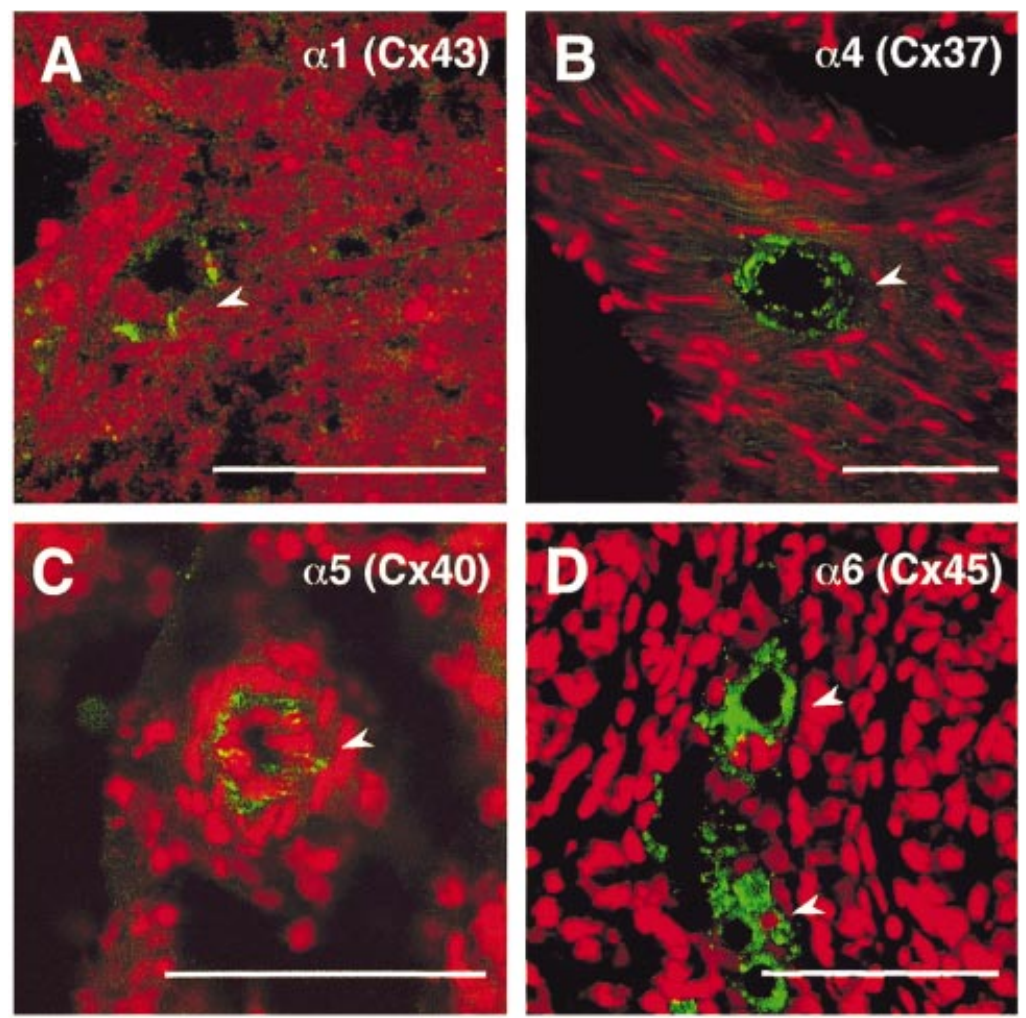

Fig. 5. Connexin expression in gap junctions within mouse ovarian follicle blood vessels. (A) Immunolabelling of $\alpha_{1}$ connexin (Cx43, arrowhead). (B) Immunolabelling of $\alpha_{4}$ connexin (Cx37, arrowhead). (C) Immunolabelling of $\alpha_{5}$ connexin (Cx40, arrowhead). (D) Immunolabelling of $\alpha_{6}$ connexin (Cx45, arrowheads). Scale bars represent $50 \mu \mathrm{m}$.

(Fig. 5). $\alpha_{5}$ connexins were expressed exclusively in blood vessels and were not detected in ovarian tissue or follicles. $\beta_{6}$ connexin (Cx30) was not detectable in ovarian tissue. Connexin $\beta_{6}$ has been found to have sequence homology with $\beta_{2}$ (Cx26); therefore, it is possible that antibodies raised to $\beta_{2}$ recognize $\beta_{6}$-containing gap junctions. However, when non-communicating cells were transfected with $\beta_{2}$ and $\beta_{6}$ connexins, no crossreactivity was observed (D. L. Becker, unpublished), confirming the specificity of $\beta_{2}$ antibodies.

\section{Discussion}

The present study examined the distribution and composition of gap junctions in developing ovarian follicles of the mouse, by following protein expression for members of the $\alpha$ and $\beta$ connexin subfamilies with antibodies specific to connexins $\alpha_{1}$ (Cx43), $\alpha_{4}(\mathrm{Cx} 37), \alpha_{5}(\mathrm{Cx} 40), \alpha_{6}(\mathrm{C} \times 45), \beta_{1}$ $(\mathrm{C} \times 32), \beta_{2}(\mathrm{C} \times 26), \beta_{4}(\mathrm{C} \times 31.1)$ and $\beta_{6}(\mathrm{C} \times 30)$. Connexin labelling was not detected in primordial follicles and only seen occasionally in primary follicles. Secondary follicles, whether in prepubertal or adult mice, always expressed gap junctions. Thus, connexin expression only became substantial after initiation of granulosa cell division. Gap junctions between granulosa cells were composed of $\alpha$ connexins $\left(\alpha_{1}, \alpha_{4}\right.$ and $\left.\alpha_{6}\right)$, whereas those between thecal cells comprised $\beta$ connexins $\left(\beta_{1}\right.$ and $\left.\beta_{2}\right)$. This rule was transgressed only in atretic follicles, where $\alpha_{1}$ connexin expression between granulosa cells decreased, whereas $\beta_{4}$ connexin could be detected. Gap junctions between the

Fig. 4. Distribution of connexin types within gap junctions of adult mouse ovarian follicles. (A) Immunolabelling of $\alpha_{6}$ connexin (Cx45)containing gap junctions with R45 (arrowhead) between granulosa cells at the edge of an antral follicle (a), but not a preantral follicle (pa). (B) Immunolabelling between thecal cells (t, arrow) and on the oocyte surface (arrowhead) by Gap 10, an antibody that recognizes $\beta$ subfamily members, and (inset) between the cumulus granulosa and the oocyte (o, arrowhead). (C) Immunolabelling of $\beta_{1}$ connexin (Cx32)-containing gap junctions with Des 1 in the theca layers (t, arrowheads) of a small antral follicle. (D) Immunolabelling of $\beta_{2}$ connexin (Cx26)-containing gap junctions between thecal cells (t) with Gap 28H. (E) Strong immunolabelling of $\alpha_{1}$ connexin (Cx43) with gap 15 in a healthy follicle $(\mathrm{h})$ and reduced immunolabelling in an atretic follicle (at) with brightly staining apoptotic nuclei (arrowheads). (F) Immunolabelling of $\beta_{4}$ connexin (Cx31.1)-containing gap junctions between granulosa cells of an atretic follicle (at) with no labelling in a healthy follicle (h). Scale bars represent $50 \mu \mathrm{m}$. 
oocyte and granulosa cells were constructed from $\beta$ subfamily connexins; in preantral follicles $\alpha_{4}$ connexin was also detected.

In prepubertal 12-day-old mice, connexin expression was restricted to the central region of the ovary, which contains secondary follicles. These follicles may be hormone responsive, reflecting the influence of hormones on gap junction expression. The expression pattern may also reflect developmental regulation, since growing follicles express gap junctions first. Toshimori and Oura (1982), using freeze-fracture techniques which can detect very small gap junctions, detected gap junctions in 7-10-dayold mice. Low $\alpha_{1}$ connexin (Cx43) expression was also detected in 11-day-old rats (Granot and Dekel, 1997).

In the healthy follicles of adult mice, $\alpha_{1}$ (Cx43) was the most abundant connexin. Moderate granulosa $\alpha_{1}$ expression began at preantral stages, along with weak $\beta_{1}$ (Cx32) and $\beta_{2}$ (Cx26) expression in the theca and $\beta_{1}, \beta_{2}$ and $\alpha_{4}$ (Cx37) expression on the oocyte surface. At antral stages, this pattern was maintained with stronger expression of $\alpha_{1}$, $\beta_{1}$ and $\beta_{2}$ and additional expression of $\alpha_{4}$ in the granulosa. In preovulatory follicles, $\alpha_{6}(\mathrm{C} \times 45)$ expression was also apparent in the granulosa. Other studies in the mouse have detected $\alpha_{1}$ and $\beta_{1}$ connexin mRNA and protein (localized to the cumulus and oocyte surface) in oocytecumulus complexes (Valdimarsson et al., 1993) and $\alpha_{1}$ connexin protein in the granulosa layer of whole follicles (Koike et al., 1993).

Simon et al. (1997) reported $\alpha_{4}$ connexin (Cx37) expression in oocyte-granulosa gap junctions. In their study, $\alpha_{4}$-knockout mice were infertile, and had lost granulosaoocyte dye transfer, indicating a loss of gap junction communication. Follicular development in these mice was arrested, with concurrent 'premature' corpus luteum formation, symptoms reminiscent of polycystic ovary syndrome (PCOS) in women. In PCOS, LH concentrations are increased (Gilling-Smith and Franks, 1993), which could cause gap junction breakdown and premature follicular maturation. In the present study, $\alpha_{4}$ connexin (detected with both Gap 23 and anti- $\alpha_{4}(\mathrm{DP})$ ) was found mostly between granulosa cells of antral follicles (in a patchy localization in early antral follicles and more widely distributed in large antral-preovulatory follicles). However, a pattern of oocyte immunolabelling (with anti- $\alpha_{4}(D P)$ ) in preantral follicles similar to that described by Simon et al. (1997) was observed in the present study. The differences in $\alpha_{4}$ immunolabelling may be due to the different strains of mice being used in the two studies (the genetic background of $\alpha_{4}$-knockouts is C57 or 129 (D. Paul, personal communication)), or to a greater specificity of $\alpha_{4}$ antibody (Gap 23) used in the present study. The phenotype seen in $\alpha_{4}$-knockout mice could also have been produced by loss of communication between granulosa cells.

Connexin expression increased with follicular size. As the number of granulosa cell layers between the oocyte and theca increase during follicle growth, the distance between the oocyte and the blood supply increases, necessitating highly efficient intercellular communication mechanisms to maintain oocyte health. Gap junctions are known to contribute to the control of cell division (for review, see Bruzzone et al., 1996); indeed, reducing $\alpha_{1}$ connexin ( $\mathrm{C}$ 43) expression reduces cell proliferation in the developing chick retina (Becker and Mobbs, 1999). $\alpha_{1}$ knockout mouse follicles develop only to the primary stage (Juneja et al., 1999) and, therefore, gap junction communication is required for granulosa proliferation during follicle maturation. Communication via gap junctions may also be important for cellular reorganization, such as in antrum development. Addition of the gap junction inhibitor lindane to granulosa-oocyte cultures inhibits follicle formation (Li and Mather, 1997).

Increased connexin expression in larger follicles may be induced by oestrogen production from granulosa cells, which increases with follicular size. Oestrogen increases $\alpha_{1}$ (Cx43) expression in the rat ovary (Schreiber et al., 1993; Wiesen and Midgley, 1993; Risek et al., 1995) and HeLa cells (Yu et al., 1994), and hormone-responsive connexin gene promoters can regulate connexin expression (De Leon et al., 1994; Yu et al., 1994). In the uterus, oestrogen and progesterone are involved in the control of gap junction activation during labour (Tabb et al., 1992; Lefebvre et al., 1995; Risek et al., 1995).

In atretic follicles, connexin expression is reduced. In rats and sheep, $\alpha_{1}$ connexin (Cx43) expression was reduced after an atresia-inducing stimulus (Wiesen and Midgley, 1994; Huet et al., 1998). The cellular mechanism of follicular atresia is apoptosis (Tilly, 1996). Gap junctions may transmit survival signals between cells and, thus, reduced intercellular communication may be part of an apoptotic cascade, with cessation of survival factor signalling resulting in global cell death in the follicle. Reduced cell contact is a feature of apoptosis (Wyllie, 1997), so reduced connexin expression may simply reflect cell death. An alternative hypothesis may be that gap junctional communication within the dying follicle may be involved in the co-ordination of atresia, which is an 'all or none' event. Expression of $\beta_{4}$ connexin $(\mathrm{C} \times 31.1)$ has been shown, in the present study, to be restricted to atretic follicles. The gap junctions may transmit apoptosis-regulating signals, co-ordinating apoptosis in all cells of an atretic follicle. Indeed, gap junctions have been shown to pass apoptotic signals between neurones and astrocytes, coordinating cell death (Lin et al., 1998).

Compartmentalization of connexin expression appears to occur in the mouse follicle, such that gap junction communication occurs between oocyte and granulosa cells, between granulosa cells and between theca cells but not between granulosa and theca cells. The granulosa and theca are physically separated by a basal lamina, through which growth factors can pass, but gap junctional communication cannot take place (Rodgers et al., 1995). There may be several reasons for this compartmentalization. The permeability and conductance of gap junctions may be influenced by cellular microenvironment, which may 
differ in cellular compartments (Bennett et al., 1988). Similar kinases may have different actions on gap junctions formed by different connexin types (Bennett et al., 1991), which may also allow discrimination of second messengers (Kumar and Gilula, 1996). Compartmentalization of gap junctions may be important in the co-ordination of hormone production in cellular compartments, for example, oestrogen from the granulosa and androgens from the theca (Grazul Bilska et al., 1997).

Differential expression of connexins in follicular compartments may be a mechanism by which global events have cell-specific effects. Oocyte maturation is an example of this, since at the LH surge, the whole ovary is exposed to the marked increase in LH. However, only preovulatory follicles respond to this event by ovulation, and smaller follicles do not, as only preovulatory follicles have sufficient LH receptors to transmit the signal (Hillier, 1994). Although LH-induced cAMP signalling is thought to interrupt granulosa-oocyte gap junction communication (Dekel, 1988; Sherizly et al., 1988; Granot and Dekel, 1994), gap junctions containing $\beta$ subfamily connexins in the theca may continue to communicate, preserving follicular function. The ovulatory follicle must remain functional through ovulation, as it develops into a corpus luteum to support the potential pregnancy.

In conclusion, this study, carried out with highly specific connexin antibodies, confirms and greatly extends previous observations on the location and changing distribution of gap junctions in mouse ovarian follicles. Thecal and oocyte-granulosa connexins are members of the $\beta$ connexin subfamily, and granulosa connexins are members of the $\alpha$ subfamily. Atretic follicles exhibit generally reduced gap junction expression, but specific upregulation of $\beta_{4}$ connexin (Cx31.1). The localization of connexins $\alpha_{6}$ $(\mathrm{C} \times 45), \beta_{1}(\mathrm{C} \times 32), \beta_{2}(\mathrm{C} \times 26)$ and $\beta_{4}$ in the intact mouse follicle is novel. The distribution and structure of follicular gap junctions reveals potential pathways for cell-cell communication between cell populations in the developing follicle. However, dye transfer experiments will be necessary to discover whether pathways revealed by connexin labelling are mirrored by functional cell-cell communication via gap junctions.

The authors would like to thank W. H. Evans (University of Cardiff) for supplying some of the antibodies used in this study, Darran Clements (University College London) for technical assistance, and Julie Richards and Wei Li Di (UCL) for the western blots of $1 \mathrm{~A}$ and $2 \mathrm{~A}$ antibodies. D. L. Becker and A. E. Warner are supported by the Royal Society, the New Zealand Marsden Fund supports J. S. Lin and C. S. Wright is supported by the Institute Trust Fund.

\section{References}

Albertini DF and Anderson E (1974) The appearance and structure of intercellular connections during the ontogeny of the rabbit ovarian follicle with particular reference to gap junctions Journal of Cell Biology $63234-250$

Ali N, Aligue R and Evans WH (1990) Highly purified bile-canalicular vesicles and lateral plasma membranes isolated from rat liver on Nycodenz gradients. Biochemical and immunolocalization studies Biochemical Journal 271 185-192

Anderson E and Albertini DF (1976) Gap junctions between the oocyte and companion follicle cells in the mammalian ovary Journal of Cell Biology 71 680-686

Becker DL and Mobbs P (1999) Connexin alpha1 and cell proliferation in the developing chick retina Experimental Neurology 156 326-332

Becker DL, Evans WH, Green CR and Warner A (1995) Functional analysis of amino acid sequences in connexin43 involved in intercellular communication through gap junctions Journal of Cell Science $\mathbf{1 0 8}$ 1455-1467

Bennett MVL, Verselis V, White RL and Spray DC (1988) Gap junctional conductance: gating. In Gap Junctions pp 287-304 Eds EL Hertzburg and RG Johnson. Allan R Liss, New York

Bennett MV, Barrio LC, Bargiello TA, Spray DC, Hertzberg E and Saez JC (1991) Gap junctions: new tools, new answers, new questions Neuron 6 305-320

Beyer EC, Reed KE, Westphale EM, Kanter HL and Larson DM (1992) Molecular cloning and expression of rat connexin40, a gap junction protein expressed in vascular smooth muscle Journal of Membrane Biology 127 69-76

Biggers JD, Whittingham DG and Donahue RP (1967) The pattern of energy metabolism in the mouse oocyte and zygote Proceedings National Academy of Sciences USA 58 560-567

Bruzzone R, White TW and Paul DL (1996) Connections with connexins: the molecular basis of direct intercellular signaling European Journal of Biochemistry 238 1-27

Burnette WN (1981) 'Western blotting': electrophoretic transfer of proteins from sodium dodecyl sulfate-polyacrylamide gels to unmodified nitrocellulose and radiographic detection with antibody and radioiodinated protein A Analytical Biochemistry 112 195-203

Carter TD, Chen XY, Carlile G, Kalapothakis E, Ogden D and Evans WH (1996) Porcine aortic endothelial gap junctions: identification and permeation by caged InsP3 Journal of Cell Science 109 1765-1773

Colaco CA and Evans WH (1981) A biochemical dissection of the cardiac intercalated disk: isolation of subcellular fractions containing fascia adherentes and gap junctions Journal of Cell Science 52 313-325

Coppen SR, Dupont E, Rothery S and Severs NJ (1998) Connexin45 expression is preferentially associated with the ventricular conduction system in mouse and rat heart Circulation Research 82 232-243

De Leon JR, Buttrick PM and Fishman GI (1994) Functional analysis of the connexin43 gene promoter in vivo and in vitro. Journal of Molecular and Cellular Cardiology 26 379-389

Dekel N (1988) Regulation of oocyte maturation. The role of cAMP Annals New York Academy of Sciences 541 211-216

Diez JA, Ahmad S and Evans WH (1999) Assembly of heteromeric connexons in guinea-pig liver en route to the Golgi apparatus, plasma membrane and gap junctions European Journal of Biochemistry 262 $142-148$

Downs SM, Daniel SA, Bornslaeger EA, Hoppe PC and Eppig JJ (1989) Maintenance of meiotic arrest in mouse oocytes by purines: modulation of cAMP levels and cAMP phosphodiesterase activity Gamete Research 23 323-334

Eppig JJ (1989) The participation of cyclic adenosine monophosphate (CAMP) in the regulation of meiotic maturation of oocytes in the laboratory mouse Journal of Reproduction and Fertility Supplement 38 3-8

Eppig JJ (1991) Intercommunication between mammalian oocytes and companion somatic cells Bioessays 13 569-574

Gilling-Smith C and Franks S (1993) Polycystic ovary syndrome Reproductive Medicine Review 2 15-32

Goliger JA and Paul DL (1994) Expression of gap junction proteins Cx26, Cx31.1, Cx37, and Cx43 in developing and mature rat epidermis Developmental Dynamics 200 1-13

Goodenough DA (1976) In vitro formation of gap junction vesicles Journal of Cell Biology 68 220-231

Granot I and Dekel N (1994) Phosphorylation and expression of connexin-43 ovarian gap junction protein are regulated by luteinizing hormone Journal of Biological Chemistry 26930 502-30 509 
Granot I and Dekel N (1997) Developmental expression and regulation of the gap junction protein and transcript in rat ovaries Molecular Reproduction and Development 47 231-239

Grazul Bilska AT, Reynolds LP and Redmer DA (1997) Gap junctions in the ovaries Biology of Reproduction 57 947-957

Grazul Bilska AT, Redmer DA, Bilski JJ, Jablonka Shariff A, Doraiswamy V and Reynolds LP (1998) Gap junction proteins, connexin 26, 32 and 43 in sheep ovaries throughout the estrous cycle Endocrine 8 269-279

Green CR, Harfst E, Gourdie RG and Severs NJ (1988) Analysis of the rat liver gap junction protein: clarification of anomalies in its molecular size Proceedings of the Royal Society of London B 233 165-174

Heller DT, Cahill DM and Schultz RM (1981) Biochemical studies of mammalian oogenesis: metabolic cooperativity between granulosa cells and growing mouse oocytes Developmental Biology 84 455-464

Hillier SG (1994) Current concepts of the roles of follicle stimulating hormone and luteinizing hormone in folliculogenesis Human Reproduction 9 188-191

Huet C, Monget P, Pisselet C, Hennequet C, Locatelli A and Monniaux D (1998) Chronology of events accompanying follicular atresia in hypophysectomized ewes. Changes in levels of steroidogenic enzymes, connexin 43, insulin-like growth factor II/mannose 6 phosphate receptor, extracellular matrix components, and matrix metalloproteinases Biology of Reproduction 58 175-185

Itahana K, Tanaka T, Morikazu Y, Komatu S, Ishida N and Takeya (1998) Isolation and characterization of a novel connexin gene, Cx-60, in porcine ovarian follicles Endocrinology 139 320-329

Johnson ML, Redmer DA, Reynolds LP and Grazul Bilska AT (1999 Expression of gap junctional proteins connexin 43, 32, and 26 throughout follicular development and atresia in cows Endocrine 10 $43-51$

Juneja SC, Barr KJ, Enders GC and Kidder GM (1999) Defects in the germ line and gonads of mice lacking connexin43 Biology of Reproduction $601263-1270$

Koike K, Watanabe H, Hiroi M and Tonosaki A (1993) Gap junction of stratum granulosum cells of mouse follicles: immunohistochemistry and electron microscopy Journal of Electron Microscopy 42 94-106

Kumar N (1999) Molecular biology of the interactions between connexins. In Gap Junction-Mediated Intercellular Signalling in Health and Disease pp 6-16 Ed. G Cardew. Novartis Foundation Symposium 219 Wiley, Chichester

Kumar NM and Gilula NB (1996) The gap junction communication channel Cell 84 381-388

Lefebvre DL, Piersanti M, Bai XH, Chen ZQ and Lye SJ (1995) Myometria transcriptional regulation of the gap junction gene, connexin-43 Reproduction, Fertility and Development 7 603-611

Lenhart JA, Downey BR and Bagnell CA (1998) Connexin 43 gap junction protein expression during follicular development in the porcine ovary Biology of Reproduction 58 583-590

Li R and Mather JP (1997) Lindane, an inhibitor of gap junction formation, abolishes oocyte directed follicle organizing activity in vitro. Endocrinology 138 4477-4480

Lin JH-C, Weigel H, Cotrina ML, Liu S, Bueno E, Hansen AJ, Hansen TW Goldman S and Nedergaard M (1998) Gap-junction-mediated propagation and amplification of cell injury Nature Neuroscience $\mathbf{1}$ 494-500

Makarenkova H, Becker DL, Tickle C and Warner AE (1997) Fibroblast growth factor 4 directs gap junction expression in the mesenchyme of the vertebrate limb bud Journal of Cell Biology 138 1125-1137
Monaghan P, Perusinghe N, Carlile G and Evans WH (1994) Rapid modulation of gap junction expression in mouse mammary gland during pregnancy, lactation, and involution Journal of Histochemistry and Cytochemistry 42 931-938

Rahman S and Evans WH (1991) Topography of connexin32 in rat liver gap junctions. Evidence for an intramolecular disulphide linkage connecting the two extracellular peptide loops Journal of Cell Science $100567-578$

Reed KE, Westphale EM, Larson DM, Wang HZ, Veenstra RD and Beyer EC (1993) Molecular cloning and functional expression of human connexin37, an endothelial cell gap junction protein Journal of Clinical Investigation 91 997-1004

Risek B, Klier FG, Phillips A, Hahn DW and Gilula NB (1995) Gap junction regulation in the uterus and ovaries of immature rats by estrogen and progesterone Journal of Cell Science 108 1017-1032

Rodgers HF, Lavranos TC, Vella CA and Rodgers RJ (1995) Basal lamina and other extracellular matrix produced by bovine granulosa cells in anchorage-independent culture Cell and Tissue Research 282 463-471

Schreiber JR, Beckmann MW, Polacek D and Davies PF (1993) Changes in gap junction connexin-43 messenger ribonucleic acid levels associated with rat ovarian follicular development as demonstrated by in situ hybridization American Journal of Obstetrics and Gynecology 168 1094-1102

Sherizly I, Galiani D and Dekel N (1988) Regulation of oocyte maturation: communication in the rat cumulus-oocyte complex Human Reproduction 3 761-766

Simon AM, Goodenough DA, Li E and Paul DL (1997) Female infertility in mice lacking connexin 37 Nature 385 525-529

Sohl G, Degen J, Teubner B and Willecke K (1998) The murine gap junction gene connexin 36 is highly expressed in mouse retina and regulated during brain development FEBS Letters 428 27-31

Tabb T, Thilander G, Grover A, Hertzberg E and Garfield R (1992) An immunochemical and immunocytologic study of the increase in myometrial gap junctions (and connexin 43) in rats and humans during pregnancy American Journal of Obstetrics and Gynecology 167 $559-567$

Tilly JL (1996) Apoptosis and ovarian function Reviews of Reproduction 1 162-172

Toshimori K and Oura C (1982) Cellular interconnections in the young mouse ovary. Freeze-fracture study Cell and Tissue Research $\mathbf{2 2 4}$ 383-395

Valdimarsson G, De Sousa PA and Kidder GM (1993) Coexpression of gap junction proteins in the cumulus-oocyte complex Molecular Reproduction and Development 36 7-15

Wiesen JF and Midgley AR, Jr (1993) Changes in expression of connexin 43 gap junction messenger ribonucleic acid and protein during ovarian follicular growth Endocrinology 133 741-746

Wiesen JF and Midgley AR, Jr (1994) Expression of connexin 43 gap junction messenger ribonucleic acid and protein during follicular atresia Biology of Reproduction 50 336-348

Wyllie AH (1997) Apoptosis: an overview British Medical Bulletin 53 451-465

Yu W, Dahl G and Werner R (1994) The connexin43 gene is responsive to oestrogen Proceedings of the Royal Society of London B 255 125-132

Received 27 March 2000

Accepted 21 July 2000. 
